\title{
Het Behandelpaspoort
}

Ester Bertholet

\section{WAT IS HET BEHANDELPASPOORT?}

Het Behandelpaspoort is een boekje in paspoortformaat dat als handvat kan dienen bij het nadenken over en beschrijven van behandelwensen. Het doel van het paspoort is dat mensen nadenken en praten over deze vragen met hun (huis)arts en naasten. Het fysiek meenemen van het paspoort kan behulpzaam zijn, maar is geen noodzaak in het contact met andere behandelaren.

Mensen kunnen aangeven wat hun behandelwensen zijn ten aanzien van reanimatie, ic- en ziekenhuisopname. De antwoordcategorieën zijn: 'altijd alles', 'sommige behandelingen niet meer' en 'alleen symptomatisch', waarbij er genoeg vrije ruimte is om uitleg en nuances aan te brengen. Daarnaast kunnen mensen in het paspoort aangeven wie hun contactpersonen/vertegenwoordigers zijn en kunnen mensen via vragen over gezondheid en ziekte aangeven wat zij belangrijk vinden.

\section{WAAROM HEBBEN WE HET BEHANDELPASPOORT NODIG?}

Het bespreken van behandelwensen is niet altijd makkelijk. Op welk moment breng je als zorgverlener of patiënt het onderwerp ter sprake? Wat bespreek je dan precies en op welke manier kan een patiënt er zelf mee aan de slag? Het Behandelpaspoort is ontwikkeld om hierin te ondersteunen, zodat mensen makkelijk in gesprek gaan met hun naasten en zorgverleners en ze een antwoord hebben op het moment dat ze erg ziek worden.

\section{DE ONTWIKKELAARS}

Het Behandelpaspoort is ontwikkeld door specialist ouderengeneeskunde Ester Bertholet, in samenwerking met een grote groep collega's en patiënten.

\section{DE EERSTE ERVARINGEN MET HET BEHANDELPASPOORT}

Het Behandelpaspoort kan zelfstandig worden ingevuld. Toch is het voor een deel van de kwetsbaarste patiënten van belang om de inhoud samen met de huisarts of $\mathrm{POH}$ door te spreken. Patiënten overschatten soms hun vitaliteit en hebben niet altijd een realistische kijk op de ernst van hun ziekte. Het Behandelpaspoort kreeg de afgelopen tijd veel aandacht en dat nam verder toe door de COVID-19-pandemie. Het ministerie van VWS stelde in april van dit jaar 45.000 Behandelpaspoorten gratis ter beschikking voor hulpverleners. Half september hebben we via een antwoordformulier om feedback gevraagd aan ruim 800 van die zorgverleners. De 200 reacties die we tot nu toe ontvingen waren positief. Als aanbeveling kregen we terug dat het paspoort gratis zou moeten zijn en digitaal beschikbaar.

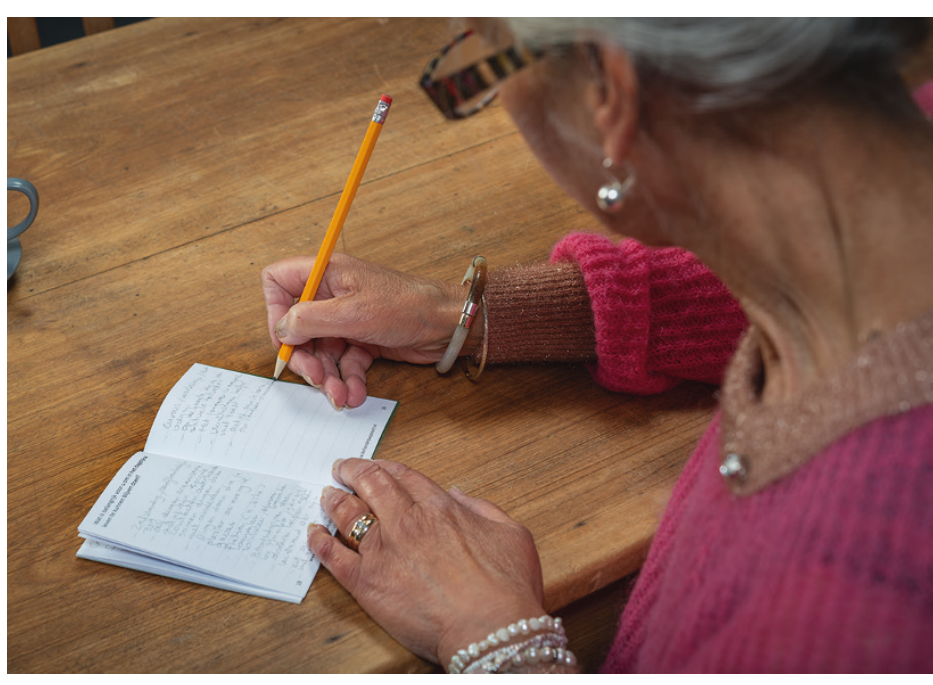

Het Behandelpaspoort geeft houvast.

Foto: Margot Scheerder

\section{TOEKOMSTPLANNEN}

Momenteel wordt het Behandelpaspoort vertaald in het Engels, daarnaast zal er ook een versie beschikbaar komen in het Arabisch en Turks. Tot slot is er aandacht voor slechtzienden/ laaggeletterden, waarbij er in de toekomst een editie beschikbaar komt met grotere letters, eenvoudiger tekst en met meer plaatjes. Als die ontwikkelingen zijn afgerond, zijn er plannen om op korte termijn de meerwaarde van het Behandelpaspoort in onderzoeksverband te bestuderen.

\section{GEBRUIKER AAN HET WOORD}

'Het Behandelpaspoort kan een gesprek over toekomstige behandelwensen goed op gang helpen. Het motiveert mensen ermee aan de slag te gaan, waarbij deze wensen goed vastgelegd kunnen worden. Het paspoort geeft ook houvast om dit onderwerp met kinderen of mantelzorger te bespreken, zodat zij ook weten wat de laatste wensen zijn,' aldus een enthousiaste huisarts.

Bertholet EA. Het Behandelpaspoort. Huisarts Wet 2020;63[12]:71. DOI:10.1007/s12445-020-0926-9.

Praktijk Ouderengeneeskunde Bertholet, Velp: drs. E.A. Bertholet: specialist ouderengeneeskunde en ontwikkelaar Behandelpaspoort, e.bertholet@pogb.nl.

Mogelijke belangenverstrengeling: EB is uitgever van het Behandelpaspoort.

www.behandelpaspoort.nl

Dit is een bijdrage in de rubriek Best practice die een platform biedt voor innovatieve ontwikkelingen in de huisartsenpraktijk. 